\title{
Potassium leaching test in evaluation of popcorn seed vigor ${ }^{1}$
}

\author{
Hugo César Rodrigues Moreira Catão*2 (D), Franciele Caixeta ${ }^{3}$ (D), \\ Ítala Menegon Castilho ${ }^{4}$, Luana de Souza Marinke ${ }^{5}$ (D), Gabriel Zanardo \\ Martins $^{6}(\mathbb{D})$, João Batista de Campos Menezes ${ }^{7}$ (D)
}

\begin{abstract}
The search for tests that offer fast and reliable information on the physiological potential of seeds is of fundamental importance for quality control programs. The aim of this study was to evaluate the efficiency of the potassium leaching test in identification of different vigor levels of popcorn seed lots. Five seed lots of the hybrids AP8203 and AP4512 were tested for moisture content, and physiological quality was evaluated by tests of germination, first count of germination, and seedling emergence in the field. These results were compared to variations in the potassium leaching test (temperatures of $25^{\circ} \mathrm{C}$ and $30{ }^{\circ} \mathrm{C}$, volumes of $50 \mathrm{~mL}$ and $75 \mathrm{~mL}$ of water, fifty and one hundred seeds, and periods of $0.5 \mathrm{~h}, 1 \mathrm{~h}, 1.5 \mathrm{~h}, 2 \mathrm{~h}, 2.5 \mathrm{~h}, 3 \mathrm{~h}, 4 \mathrm{~h}$ and $5 \mathrm{~h}$ ). Results showed that the potassium leaching test is efficient in separating the popcorn seed lots regarding physiological potential, and the most adequate conditions for this test are the use of fifty seeds with $50 \mathrm{~mL}$ of water for two hours at $30^{\circ} \mathrm{C}$.
\end{abstract}

Index terms: Zea mays everta, seed vigor, membrane integrity.

\section{Teste de lixiviação de potássio na avaliação do vigor de sementes de milho pipoca}

\begin{abstract}
RESUMO - A busca por testes que ofereçam rapidez e informações seguras sobre o potencial fisiológico das sementes, torna-se de fundamental importância para programas de controle de qualidade. O objetivo deste trabalho foi avaliar a eficiência do teste de lixiviação de potássio na identificação de diferentes níveis de vigor de lotes de sementes de milho pipoca. Cinco lotes de sementes dos híbridos AP8203 e AP4512 foram submetidos à determinação do teor de água e à avaliação da qualidade fisiológica por meio dos testes de germinação, primeira contagem de germinação, emergência de plântulas em campo e os resultados comparados as variações no teste de lixiviação de potássio (temperaturas de $25^{\circ} \mathrm{C}$ e $30^{\circ} \mathrm{C}$; volumes de $50 \mathrm{~mL}$ e $75 \mathrm{~mL}$ de água; cinquenta e cem sementes; e períodos de 0.5 h, 1 h, 1.5 h, 2 h, 2.5 h, 3, 4 e 5 h). Pelos resultados obtidos verificou-se que o teste de lixiviação de potássio é eficiente na separação dos lotes de sementes de milho pipoca com relação ao potencial fisiológico e a condição mais adequada para a realização deste teste é a utilização de cinquenta sementes com $50 \mathrm{~mL}$ de água, por duas horas, a $30^{\circ} \mathrm{C}$.
\end{abstract}

Termos para indexação: Zea mays everta, vigor de sementes, integridade de membranas.

\section{Introduction}

The offer of Brazilian hybrids of popcorn (Zea mays L. everta) with high yield and adaptation to edaphic and climatic conditions is small, which leads to importation of a large number of popcorn seeds (Catão and Caixeta, 2017). However, popcorn production is growing and is an advantageous source

${ }^{1}$ Submitted on 4/20/2019. Accepted for publication on 8/12/2019.

${ }^{2}$ Instituto de Ciências Agrárias, Universidade Federal de Uberlândia, 38410-337 - Uberlândia, MG, Brasil.

${ }^{3}$ General Mills Brasil Alimentos Ltda. R. Benjamin Constant, 17, 86390-000 Cambará, PR, Brasil.

${ }^{4}$ Faculdades Integradas de Ourinhos, Departamento de Agronomia, 19909-100

- Ourinhos, SP, Brasil. of income due to added value of the product (Rocha et al., 2018; Kavan et al., 2019). This growth is due, in part, to the selection, development, and adaptation of imported cultivars for the climate conditions of Brazil (Catão and Caixeta, 2017).

The use of seeds with high physiological potential is a preponderant factor for establishment of a successful crop (Catão et al., 2013). Thus, seed technology has sought to refine the tests

${ }^{5}$ Universidade Estadual de Londrina, Departamento de Agronomia, Caixa Postal 10.011, 86057-970 - Londrina, PR, Brasil.

${ }^{6}$ Universidade Estadual Norte Paraná, 86360-000 - Bandeirantes, PR, Brasil. ${ }^{7}$ Universidade Federal Minas Gerais, Instituto Ciências Agrárias, 39404-547 Montes Claros, MG, Brasil.

*Corresponding author $<$ hugo.catao@ufu.br $>$ 
used to evaluate physiological potential, aiming for the results to express the performance potential of the lot to minimize the risk of using low quality seeds (Bittencourt et al., 2012).

The characteristics of a seed lot can be evaluated by diverse tests that follow strict standards. Seed quality is routinely evaluated by the standard germination test, conducted under optimal environment conditions (Brasil, 2009). However, the result of that test overestimates the true values of plant emergence in the field, and results obtained from vigor tests are also necessary (Bertolin et al., 2011). The ideal procedure is for vigor tests to be used together with the germination test to assist in decision making and increase the speed and efficiency of quality control (Bittencourt et al., 2012).

Studies in seed technology have reported that rapid vigor test that produce consistent information are those related to physiological deterioration processes, such as those related to enzymatic and respiratory activities and cell membrane integrity. The electrical conductivity and potassium leaching tests fit in this category (Steiner et al., 2011; Souza et al., 2014).

The potassium leaching test is based on the same principle as the electrical conductivity test, through evaluation of cell membrane integrity, only the parameter analyzed is changed. In this test, only the potassium ion $\left(\mathrm{K}^{+}\right)$is quantified in the soaking solution. Lower vigor seeds have lower speed of structuring of membranes when soaked in water, and a consequence is greater release of exudates from the cell and, consequently, greater release of potassium (Marcos-Filho, 2015).

The potassium leaching test requires from one to two hours to obtain results, thus allowing seed vigor to be evaluated in a fast and efficient manner (Marcos-Filho, 2015). This is fundamental for speeding decision making, especially in relation to the operations of harvest, processing, and sale (Marcos-Filho, 2015).

Thus, the potassium leaching test has become prominent for evaluation of seed physiological potential, resulting in satisfactory data for various species, as for example triticale (Steiner et al., 2011), rice (Barbieri et al., 2011), and wheat (Douradinho et al., 2015). However, data regarding use of the potassium leaching test in evaluation of popcorn seed vigor are only in the initial stage. Given this lack of information, the aim of this study was to determine the potential of the potassium leaching test in evaluation of the physiological quality of popcorn seeds.

\section{Material and Methods}

The study was conducted in the Seed Laboratory of the Plant Science Department of the Fundação Gammon de Ensino in Paraguaçu Paulista, São Paulo, using five seed lots from two popcorn cultivars (AP8203 and AP4512). Moisture content was determined and physiological quality was evaluated for samples from each lot and cultivar using the germination, first count of germination, and seedling emergence tests and specific procedures for carrying out the potassium leaching test.

Moisture content was determined by the oven method at $105 \pm 3{ }^{\circ} \mathrm{C}$ for 24 hours using two subsamples of approximately $10 \mathrm{~g}$ for each lot (Brasil, 2009).

In the germination test, four replications of fifty seeds were used for each lot. The seeds were uniformly distributed on two sheets of germitest paper, moistened with distilled water in the amount of 2.5 times the weight of the dry paper, and placed in a Mangelsdorf germinator at $25{ }^{\circ} \mathrm{C}$ with a 12 -h photoperiod. The germination counts were made at four and seven days after sowing for determination of the percentage of normal seedlings (Brasil, 2009). The results were expressed in percentage of germination in the first count and in the final count.

For the emergence test, four subsamples of fifty seeds from each lot were sown in the field, distributed at a depth of $3.0 \mathrm{~cm}$ and a spacing of $0.5 \mathrm{~cm}$ in furrows of $1.0 \mathrm{~m}$ length. The soil was moistened to approximately $60 \%$ of water retention capacity. On the tenth day after stabilization of stand, the number of emerged seedlings was counted and the results were expressed in percentage.

The effects of the soaking period $(0.5 \mathrm{~h}, 1 \mathrm{~h}, 1.5 \mathrm{~h}, 2 \mathrm{~h}$, $2.5 \mathrm{~h}, 3 \mathrm{~h}, 4 \mathrm{~h}$ and $5 \mathrm{~h}$ ), of the volume of deionized water (50 and $75 \mathrm{~mL}$ ), of the number of seeds (50 and 100), and of the soaking temperature $\left(25^{\circ} \mathrm{C}\right.$ and $\left.30{ }^{\circ} \mathrm{C}\right)$ were studied in the potassium leaching test. The test was conducted using four subsamples of 50 or 100 seeds that were first weighed (precision of $0.0001 \mathrm{~g}$ ), placed in plastic cups containing deionized water, and kept in a germinator for each period and at the temperatures predetermined for soaking. Readings were made directly through atomic absorption using a flame spectrophotometer. For calculation of potassium leaching, the reading obtained in the flame spectrophotometer, the volume of deionized water used $(\mathrm{mL})$, and the weight of the samples (g) were considered. The result was expressed in $\mu \mathrm{g}$ of $\mathrm{K} / \mathrm{g}$ of seed, i.e., ppm of potassium.

Analyses of variance were performed separately for each cultivar and test conducted using a completely randomized design with four replications. In the event of significant effects, the mean values were compared by the Tukey test at 5\% probability, using the Sisvar 5.0 software (Ferreira, 2011). Pearson linear correlation analysis was also performed among the results of the tests of evaluation of seed physiological quality and the emergence test. 


\section{Results and Discussion}

The initial evaluation of physiological quality and moisture content of the popcorn seed lots are shown in Table 1. The data referring to moisture content were similar among the popcorn seed lots studied. This is important for carrying out the tests because uniformity of the initial seed moisture content contributes to obtaining consistent results (Marcos-Filho, 2015). Furthermore, Guedes et al. (2011) emphasized that differences from $1-2 \%$ in moisture content among samples do not compromise results and tests can be performed.

The germination test showed that lot 4 of the hybrid AP8203 has lower physiological quality, with a statistical difference from the others, i.e., lots 1,2,3 and 5 were clustered at the same vigor level and did not differ from each other. The tests of first count of germination and seedling emergence in the field also confirmed that lot 4 was of inferior quality and highlighted lots 1,3 and 5 as having higher vigor, without a statistical difference from each other. Lot 2 proved to be intermediate.

The results of seed lots of AP4512 hybrid popcorn did not differ from each other in the germination test. However, high and similar results in the germination test do not necessarily mean that all the lots have high vigor, since the germination test is conducted under favorable environmental conditions, allowing the seed lot to express maximum potential for production of normal seedlings (Marcos-Filho, 2015).

For Araujo et al. (2011), seed lots with similar germination are fundamental for studies that aim to determine the method for evaluation of seed vigor because the aim is to discriminate seed lots with similar levels of germination. If the germination potentials of the seeds show accentuated differences, the germination test itself is able to detect differences in seed physiological potential (Marcos-Filho and Novembre, 2009).

In this respect, the tests of first count of germination and seedling emergence in the field exhibited greater sensitivity, indicating lower physiological quality of the seeds of lots 8 and 9 of the hybrid AP4512. According to Nakagawa (1999), the first count of the germination test is considered an indication of vigor and it is an important evaluation in identifying seed lots with capacity for faster establishment, and it is conducted at the same time as the germination test.

The emergence test, for its part, is considered the best indicator for making inferences on seed vigor because it should simulate conditions that seeds will be subjected to at the time of sowing in the field (Guedes et al., 2011). Thus, the purpose of the vigor tests is to rank the seed lots, and the lots should be associated with performance of seedlings in the field, so as to monitor the efficiency of the procedures adopted in the laboratory (Marcos-Filho, 2015). These procedures were verified in the studies of Douradinho et al. (2015) with wheat seeds, and of Catão and Caixeta (2019) with soybean seeds.

The data obtained for the potassium leaching test of the different popcorn seed lots involving the combinations of number of seeds / water volume / temperature are shown in Tables 2 to 5 . At $25^{\circ} \mathrm{C}$, regardless of using 50 or 100 seeds and varying the water volume $(50$ or $75 \mathrm{~mL})$, it was not possible to separate the lots into intermediate levels of vigor (Tables 2 and 3). This behavior was also found at $30^{\circ} \mathrm{C}$ using 100 seeds (Table 5). Under these conditions, recommending the potassium leaching test for popcorn seeds would not be

Table 1. Initial quality of five lots of hybrid popcorn seeds, AP8203 and AP4512.

\begin{tabular}{cccccc}
\hline \multirow{2}{*}{ Hybrid } & Lot & Moisture content & Germination & First count & Emergence \\
\cline { 2 - 6 } & 1 & 12.9 & $98 \mathrm{a}$ & $96 \mathrm{a}$ & $98 \mathrm{a}$ \\
& 2 & 12.2 & $93 \mathrm{a}$ & $82 \mathrm{~b}$ & $89 \mathrm{~b}$ \\
AP8203 & 3 & 12.7 & $97 \mathrm{a}$ & $94 \mathrm{a}$ & $96 \mathrm{a}$ \\
& 4 & 11.8 & $85 \mathrm{~b}$ & $73 \mathrm{c}$ & $78 \mathrm{c}$ \\
& 5 & 12.5 & $96 \mathrm{a}$ & $95 \mathrm{a}$ & $97 \mathrm{a}$ \\
\hline CV (\%) & & 3.3 & 4.0 & 6.2 \\
\hline \multirow{4}{*}{ AP4512 } & 6 & 11.1 & $96 \mathrm{a}$ & $96 \mathrm{a}$ & $96 \mathrm{a}$ \\
& 7 & 12.3 & $98 \mathrm{a}$ & $84 \mathrm{~b}$ & $89 \mathrm{~b}$ \\
& 8 & 11.7 & $94 \mathrm{a}$ & $72 \mathrm{c}$ & $75 \mathrm{c}$ \\
& 9 & 10.9 & $94 \mathrm{a}$ & $73 \mathrm{c}$ & $76 \mathrm{c}$ \\
\hline
\end{tabular}

Mean values followed by the same letter in the column do not statistically differ from each other by the Tukey test at $5 \%$ probability. 
Table 2. Mean data obtained for potassium leaching ( $\mu \mathrm{g} \mathrm{K} / \mathrm{g}$ ) using the combinations of 50 seeds $/ 50 \mathrm{~mL}$ of water and 50 seeds $/ 75 \mathrm{~mL}$ of water at $25^{\circ} \mathrm{C}$ of five lots of hybrid popcorn seeds, AP8203 and AP4512.

\begin{tabular}{|c|c|c|c|c|c|c|c|c|c|}
\hline \multirow{3}{*}{ Hybrid } & \multirow{3}{*}{ Lot } & \multicolumn{8}{|c|}{ Soaking period } \\
\hline & & 0.5 & 1 & 1.5 & 2 & 2.5 & 3 & 4 & 5 \\
\hline & & \multicolumn{8}{|c|}{50 seeds $/ 50 \mathrm{~mL} / 25^{\circ} \mathrm{C}$} \\
\hline \multirow{6}{*}{ AP8203 } & 1 & $425 \mathrm{a}$ & $518 \mathrm{a}$ & $688 \mathrm{a}$ & $721 \mathrm{a}$ & $821 \mathrm{a}$ & $823 \mathrm{a}$ & $932 \mathrm{a}$ & $960 \mathrm{a}$ \\
\hline & 2 & $877 \mathrm{~b}$ & $1084 \mathrm{~b}$ & $1151 \mathrm{~b}$ & $1204 \mathrm{~b}$ & $1267 \mathrm{c}$ & $1279 \mathrm{c}$ & $1284 \mathrm{~b}$ & $1298 \mathrm{~b}$ \\
\hline & 3 & $463 \mathrm{a}$ & 537 a & 659 a & $736 \mathrm{a}$ & $784 \mathrm{a}$ & $816 \mathrm{a}$ & $905 \mathrm{a}$ & $927 \mathrm{a}$ \\
\hline & 4 & $470 \mathrm{a}$ & $552 \mathrm{a}$ & $675 \mathrm{a}$ & 793 a & $870 \mathrm{~b}$ & $903 \mathrm{~b}$ & $981 \mathrm{ab}$ & $1216 b$ \\
\hline & 5 & $811 \mathrm{~b}$ & $915 \mathrm{~b}$ & $976 \mathrm{~b}$ & $1054 \mathrm{~b}$ & $1232 \mathrm{bc}$ & $1157 \mathrm{bc}$ & $1173 \mathrm{~b}$ & $1193 \mathrm{~b}$ \\
\hline & & \multicolumn{8}{|c|}{$\mathrm{CV}(\%)=3.8$} \\
\hline \multirow{7}{*}{ AP4512 } & 6 & $763 \mathrm{a}$ & $839 \mathrm{a}$ & $880 \mathrm{a}$ & $881 \mathrm{a}$ & $893 \mathrm{a}$ & $894 \mathrm{a}$ & $905 \mathrm{a}$ & $965 \mathrm{a}$ \\
\hline & 7 & $1241 \mathrm{~b}$ & $1347 b$ & $1404 \mathrm{~b}$ & $1422 b$ & $1427 \mathrm{~b}$ & $1436 \mathrm{~b}$ & $1436 \mathrm{~b}$ & $1438 \mathrm{~b}$ \\
\hline & 8 & $1608 \mathrm{c}$ & $1676 \mathrm{c}$ & $1735 \mathrm{c}$ & $1758 \mathrm{c}$ & $1812 \mathrm{c}$ & $1819 \mathrm{c}$ & $1819 \mathrm{c}$ & $1822 \mathrm{c}$ \\
\hline & 9 & $869 \mathrm{ab}$ & $961 \mathrm{ab}$ & $1043 \mathrm{ab}$ & $1064 \mathrm{ab}$ & $1081 \mathrm{ab}$ & $1092 \mathrm{ab}$ & $1092 \mathrm{ab}$ & $1113 \mathrm{ab}$ \\
\hline & 10 & $674 \mathrm{a}$ & $764 \mathrm{a}$ & $882 \mathrm{a}$ & 879 a & 893 a & $944 \mathrm{a}$ & $944 \mathrm{a}$ & $967 \mathrm{a}$ \\
\hline & & \multicolumn{8}{|c|}{$\mathrm{CV}(\%)=4.1$} \\
\hline & & \multicolumn{8}{|c|}{50 seeds $/ 75 \mathrm{~mL} / 25^{\circ} \mathrm{C}$} \\
\hline \multirow{6}{*}{ AP8203 } & 1 & $371 \mathrm{a}$ & $473 \mathrm{a}$ & $635 \mathrm{a}$ & $674 \mathrm{a}$ & $771 \mathrm{a}$ & $773 \mathrm{a}$ & $889 \mathrm{a}$ & $915 \mathrm{a}$ \\
\hline & 2 & $822 \mathrm{~b}$ & $1038 \mathrm{c}$ & $1097 \mathrm{~b}$ & $1158 \mathrm{~b}$ & $1215 b$ & $1224 \mathrm{c}$ & $1232 \mathrm{c}$ & $1246 b$ \\
\hline & 3 & $418 \mathrm{a}$ & $487 \mathrm{a}$ & $606 \mathrm{a}$ & $686 \mathrm{a}$ & 738 a & 768 a & 857 a & 878 a \\
\hline & 4 & $420 \mathrm{a}$ & $493 \mathrm{a}$ & $622 \mathrm{a}$ & $744 \mathrm{a}$ & 821 a & $859 \mathrm{~b}$ & $936 \mathrm{~b}$ & $1162 b$ \\
\hline & 5 & $759 \mathrm{~b}$ & $865 \mathrm{~b}$ & $920 \mathrm{~b}$ & $1009 \mathrm{~b}$ & $1080 \mathrm{~b}$ & $1103 \mathrm{bc}$ & $1120 \mathrm{bc}$ & $1131 \mathrm{~b}$ \\
\hline & & \multicolumn{8}{|c|}{$\mathrm{CV}(\%)=3.9$} \\
\hline \multirow{6}{*}{ AP4512 } & 6 & $714 \mathrm{a}$ & $782 \mathrm{a}$ & $832 \mathrm{a}$ & $834 \mathrm{a}$ & $840 \mathrm{a}$ & $842 \mathrm{a}$ & $854 \mathrm{a}$ & $903 \mathrm{a}$ \\
\hline & 7 & $1198 \mathrm{~b}$ & $1298 \mathrm{~b}$ & $1353 \mathrm{~b}$ & $1369 \mathrm{~b}$ & $1372 \mathrm{~b}$ & $1378 \mathrm{~b}$ & $1386 \mathrm{~b}$ & $1389 \mathrm{~b}$ \\
\hline & 8 & $1556 \mathrm{c}$ & $1629 \mathrm{c}$ & $1689 \mathrm{c}$ & $1706 \mathrm{c}$ & $1757 \mathrm{c}$ & $1761 \mathrm{c}$ & $1762 \mathrm{c}$ & $1767 \mathrm{c}$ \\
\hline & 9 & $811 \mathrm{ab}$ & $907 \mathrm{ab}$ & $995 \mathrm{ab}$ & $1018 \mathrm{ab}$ & $1032 \mathrm{ab}$ & $1033 \mathrm{ab}$ & $1040 \mathrm{ab}$ & $1055 \mathrm{ab}$ \\
\hline & 10 & $624 \mathrm{a}$ & $714 \mathrm{a}$ & $776 \mathrm{a}$ & $830 \mathrm{a}$ & 833 a & 833 a & 884 a & $914 \mathrm{a}$ \\
\hline & & \multicolumn{8}{|c|}{$\mathrm{CV}(\%)=4.3$} \\
\hline
\end{tabular}

Mean values followed by the same letter in the column do not statistically differ from each other by the Tukey test at $5 \%$ probability.

Table 3. Mean data obtained for potassium leaching ( $\mu \mathrm{g} \mathrm{K} / \mathrm{g}$ ) using the combinations of $100 \mathrm{seeds} / 50 \mathrm{~mL}$ of water and 100 seeds $/ 75 \mathrm{~mL}$ of water at $25^{\circ} \mathrm{C}$ of five lots of hybrid popcorn seeds, AP8203 and AP4512.

\begin{tabular}{|c|c|c|c|c|c|c|c|c|c|}
\hline \multirow{3}{*}{ Hybrid } & \multirow{3}{*}{ Lot } & \multicolumn{8}{|c|}{ Soaking period } \\
\hline & & 0.5 & 1 & 1.5 & 2 & 2.5 & 3 & 4 & 5 \\
\hline & & \multicolumn{8}{|c|}{100 seeds $/ 50 \mathrm{~mL} / 25^{\circ} \mathrm{C}$} \\
\hline \multirow{6}{*}{ AP8203 } & 1 & $526 \mathrm{a}$ & $652 \mathrm{a}$ & $727 \mathrm{a}$ & $775 \mathrm{a}$ & $830 \mathrm{a}$ & $864 \mathrm{a}$ & $913 \mathrm{a}$ & $916 \mathrm{a}$ \\
\hline & 2 & $715 \mathrm{~b}$ & $925 \mathrm{~b}$ & $985 \mathrm{~b}$ & $1056 \mathrm{~b}$ & $1081 \mathrm{~b}$ & $1162 \mathrm{~b}$ & $1205 \mathrm{~b}$ & $1278 \mathrm{~b}$ \\
\hline & 3 & $502 \mathrm{a}$ & $622 \mathrm{a}$ & $696 a$ & $732 \mathrm{a}$ & $775 \mathrm{a}$ & $797 \mathrm{a}$ & $859 \mathrm{a}$ & $911 \mathrm{a}$ \\
\hline & 4 & $778 \mathrm{~b}$ & $1060 \mathrm{~b}$ & $1125 \mathrm{~b}$ & $1188 \mathrm{~b}$ & $1206 \mathrm{~b}$ & $1240 \mathrm{~b}$ & $1288 \mathrm{~b}$ & $1329 \mathrm{~b}$ \\
\hline & 5 & $499 \mathrm{a}$ & $652 \mathrm{a}$ & $625 a$ & $719 \mathrm{a}$ & $765 \mathrm{a}$ & $805 \mathrm{a}$ & $851 \mathrm{a}$ & $912 \mathrm{a}$ \\
\hline & & \multicolumn{8}{|c|}{$\mathrm{CV}(\%)=4.0$} \\
\hline
\end{tabular}

Continue... 
Table 3. Continuation.

\begin{tabular}{|c|c|c|c|c|c|c|c|c|c|}
\hline \multirow{3}{*}{ Hybrid } & \multirow{3}{*}{ Lot } & \multicolumn{8}{|c|}{ Soaking period } \\
\hline & & 0.5 & 1 & 1.5 & 2 & 2.5 & 3 & 4 & 5 \\
\hline & & \multicolumn{8}{|c|}{100 seeds $/ 50 \mathrm{~mL} / 25^{\circ} \mathrm{C}$} \\
\hline \multirow{7}{*}{ AP4512 } & 6 & $796 \mathrm{a}$ & $859 \mathrm{a}$ & $862 \mathrm{a}$ & $894 \mathrm{a}$ & 919 a & $944 \mathrm{a}$ & $952 \mathrm{a}$ & $1002 \mathrm{a}$ \\
\hline & 7 & $685 \mathrm{a}$ & $763 \mathrm{a}$ & $827 \mathrm{a}$ & $837 \mathrm{a}$ & $854 \mathrm{a}$ & 899 a & 939 a & $976 \mathrm{a}$ \\
\hline & 8 & $1398 \mathrm{~b}$ & $1496 \mathrm{~b}$ & $1510 \mathrm{~b}$ & $1512 \mathrm{~b}$ & $1525 \mathrm{~b}$ & $1535 \mathrm{~b}$ & $1568 \mathrm{~b}$ & $1584 \mathrm{~b}$ \\
\hline & 9 & $1259 \mathrm{~b}$ & $1338 \mathrm{~b}$ & $1339 \mathrm{~b}$ & $1341 \mathrm{~b}$ & $1353 \mathrm{~b}$ & $1364 \mathrm{~b}$ & $1374 \mathrm{~b}$ & $1405 \mathrm{~b}$ \\
\hline & 10 & $750 \mathrm{a}$ & $842 \mathrm{a}$ & $924 \mathrm{a}$ & $930 \mathrm{a}$ & $969 \mathrm{a}$ & $1003 \mathrm{a}$ & $1057 \mathrm{a}$ & $1101 \mathrm{a}$ \\
\hline & & \multicolumn{8}{|c|}{$\mathrm{CV}(\%)=3.9$} \\
\hline & & \multicolumn{8}{|c|}{100 seeds $/ 75 \mathrm{~mL} / 25^{\circ} \mathrm{C}$} \\
\hline \multirow{6}{*}{ AP8203 } & 1 & $493 \mathrm{a}$ & $622 \mathrm{a}$ & $692 \mathrm{a}$ & $736 \mathrm{a}$ & $805 \mathrm{a}$ & 832 a & 849 a & $887 \mathrm{a}$ \\
\hline & 2 & $684 \mathrm{~b}$ & $881 \mathrm{~b}$ & $951 \mathrm{~b}$ & $1025 \mathrm{~b}$ & $1057 \mathrm{~b}$ & $1128 \mathrm{~b}$ & $1168 \mathrm{~b}$ & $1243 \mathrm{~b}$ \\
\hline & 3 & $468 \mathrm{a}$ & $590 \mathrm{a}$ & $665 \mathrm{a}$ & $707 \mathrm{a}$ & $740 \mathrm{a}$ & $765 \mathrm{a}$ & $824 \mathrm{a}$ & $881 \mathrm{a}$ \\
\hline & 4 & $749 \mathrm{~b}$ & $1042 \mathrm{~b}$ & $1082 \mathrm{~b}$ & $1142 \mathrm{~b}$ & $1174 \mathrm{~b}$ & $1210 \mathrm{~b}$ & $1254 \mathrm{~b}$ & $1297 \mathrm{~b}$ \\
\hline & 5 & $465 \mathrm{a}$ & $599 \mathrm{a}$ & $626 \mathrm{a}$ & $684 \mathrm{a}$ & $734 \mathrm{a}$ & $772 \mathrm{a}$ & $819 a$ & $887 \mathrm{a}$ \\
\hline & & \multicolumn{8}{|c|}{$\mathrm{CV}(\%)=4.1$} \\
\hline \multirow{6}{*}{ AP4512 } & 6 & $765 \mathrm{a}$ & 822 a & $823 \mathrm{a}$ & $866 \mathrm{a}$ & $883 \mathrm{a}$ & 901 a & 911 a & $979 \mathrm{a}$ \\
\hline & 7 & $647 \mathrm{a}$ & $727 \mathrm{a}$ & $790 \mathrm{a}$ & $804 \mathrm{a}$ & $824 \mathrm{a}$ & 852 a & $906 \mathrm{a}$ & $932 \mathrm{a}$ \\
\hline & 8 & $1353 \mathrm{~b}$ & $1455 \mathrm{~b}$ & $1484 \mathrm{~b}$ & $1489 \mathrm{~b}$ & $1492 \mathrm{~b}$ & $1496 \mathrm{~b}$ & $1532 \mathrm{~b}$ & $1555 \mathrm{~b}$ \\
\hline & 9 & $1226 \mathrm{~b}$ & $1305 \mathrm{~b}$ & $1315 b$ & $1316 \mathrm{~b}$ & $1321 \mathrm{~b}$ & $1324 b$ & $1345 b$ & $1374 \mathrm{~b}$ \\
\hline & 10 & 729 a & $802 \mathrm{a}$ & 897 a & $901 \mathrm{a}$ & $9355 \mathrm{a}$ & $975 \mathrm{a}$ & 1029 a & $1077 \mathrm{a}$ \\
\hline & & \multicolumn{8}{|c|}{$\mathrm{CV}(\%)=4.2$} \\
\hline
\end{tabular}

Mean values followed by the same letter in the column do not statistically differ from each other by the Tukey test at $5 \%$ probability.

viable. However, the use of this test at the temperature of 25 or $30^{\circ} \mathrm{C}$ with water volume of 50 or $75 \mathrm{~mL}$ was effective for evaluation of physiological quality of the seed lots of Mimosa caesalpiniifolia (Avelino et al.; 2018), Encholirium spectabile (Araújo and Silva, 2018), wheat (Douradinho et al.; 2015), and triticale (Steiner et al.; 2011).

Nevertheless, it should be noted that use of the combination of fifty seeds with $50 \mathrm{~mL}$ of water at $30{ }^{\circ} \mathrm{C}$ (Table 4) allowed stratification of the popcorn seed lots for both hybrids beginning at 2 hours of soaking. Lot 4 of the AP8203 hybrid was indicated by the potassium leaching test as having the lowest physiological potential. Lots 1, 3 and 5 had the best physiological quality, and lot 2 was classified as intermediate. For the AP4512 hybrid, lots 6 and 10 were classified as having the best physiological potential; lot 7 is intermediate; and lots 8 and 9 have lower performance. These results corroborate the data of the first count of germination test and field emergence test (Table 1).

The potassium leaching test also proved to be effective in discriminating the seed lots of sweet corn (Zea mays L.) regarding physiological potential (Zucareli et al., 2013). Souza et al. (2014) also found that seed lots of cotton (Gossypium hirsutum) were stratified in two vigor classes (high and low).
Thus, determination of this ion by the potassium leaching test has proven to be suitable for evaluation of seed physiological quality (Barbieri et al., 2011).

A big advantage of using the potassium leaching test in evaluation of popcorn seed vigor was its ability to provide fast results. As of two hours, it was already possible to separate the lots into different vigor classes (Table 4). For Marcos-Filho (2015), determination of differences among seed lots after thirty minutes of soaking is a factor to take into consideration, because this is a big advantage of the potassium leaching test over electrical conductivity, which requires at least 24 hours to make readings. It is also noteworthy that the temperature of $30{ }^{\circ} \mathrm{C}$ accelerated leaching of exudates, because, in addition to the temperature, this leaching may be affected by the degree of deterioration, damage to the seed coat, stage of development at the time of harvest, and damage caused by the speed and time of soaking (Gonzáles et al., 2011).

Analysis of the correlation between the data on evaluation of popcorn seed physiological quality and on seedling emergence in the field (Table 6) indicated that the germination test and first count of germination test were positively and significantly 
Table 4. Mean data obtained for potassium leaching ( $\mu \mathrm{g} \mathrm{K} / \mathrm{g}$ ) using the combinations of 50 seeds $/ 50 \mathrm{~mL}$ of water and 50 seeds $/ 75 \mathrm{~mL}$ of water at $30^{\circ} \mathrm{C}$ of five lots of hybrid popcorn seeds, AP8203 and AP4512.

\begin{tabular}{|c|c|c|c|c|c|c|c|c|c|}
\hline \multirow{3}{*}{ Hybrid } & \multirow{3}{*}{ Lot } & \multicolumn{8}{|c|}{ Soaking period } \\
\hline & & 0.5 & 1 & 1.5 & 2 & 2.5 & 3 & 4 & 5 \\
\hline & & \multicolumn{8}{|c|}{50 seeds $/ 50 \mathrm{~mL} / 30^{\circ} \mathrm{C}$} \\
\hline \multirow{6}{*}{ AP8203 } & 1 & $515 \mathrm{a}$ & $707 \mathrm{a}$ & $792 \mathrm{a}$ & $873 \mathrm{a}$ & $907 \mathrm{a}$ & $974 \mathrm{a}$ & $1041 \mathrm{a}$ & $1176 \mathrm{a}$ \\
\hline & 2 & $891 \mathrm{~b}$ & $982 \mathrm{~b}$ & $1105 \mathrm{~b}$ & $1185 \mathrm{~b}$ & $1219 \mathrm{~b}$ & $1332 \mathrm{~b}$ & $1366 \mathrm{~b}$ & $1478 \mathrm{~b}$ \\
\hline & 3 & $486 \mathrm{a}$ & $639 \mathrm{a}$ & $736 \mathrm{a}$ & $805 \mathrm{a}$ & $836 \mathrm{a}$ & $903 \mathrm{a}$ & 979 a & $1065 \mathrm{a}$ \\
\hline & 4 & $932 \mathrm{~b}$ & $1082 \mathrm{~b}$ & $1164 \mathrm{~b}$ & $1416 \mathrm{c}$ & $1545 \mathrm{c}$ & $1610 \mathrm{c}$ & $1651 \mathrm{c}$ & $1767 \mathrm{c}$ \\
\hline & 5 & $513 \mathrm{a}$ & $690 \mathrm{a}$ & $761 \mathrm{a}$ & $824 \mathrm{a}$ & $903 \mathrm{a}$ & $947 \mathrm{a}$ & $1035 \mathrm{a}$ & $1109 \mathrm{a}$ \\
\hline & & \multicolumn{8}{|c|}{$\mathrm{CV}(\%)=4.3$} \\
\hline \multirow{7}{*}{ AP4512 } & 6 & 846 a & 926 a & 935 a & $981 \mathrm{a}$ & $982 \mathrm{a}$ & $994 \mathrm{a}$ & $1124 \mathrm{a}$ & $1168 \mathrm{a}$ \\
\hline & 7 & $1339 \mathrm{~b}$ & $1341 \mathrm{~b}$ & $1379 \mathrm{~b}$ & $1395 \mathrm{~b}$ & $1398 \mathrm{~b}$ & $1406 \mathrm{~b}$ & $1412 \mathrm{~b}$ & $1449 \mathrm{~b}$ \\
\hline & 8 & $1515 b$ & $1608 \mathrm{~b}$ & $1613 \mathrm{~b}$ & $1621 \mathrm{c}$ & $1635 \mathrm{c}$ & $1651 \mathrm{c}$ & $1729 \mathrm{c}$ & $1746 \mathrm{c}$ \\
\hline & 9 & $1489 \mathrm{~b}$ & $1582 \mathrm{~b}$ & $1625 \mathrm{~b}$ & $1639 \mathrm{c}$ & $1664 \mathrm{c}$ & $1739 \mathrm{c}$ & $1744 \mathrm{c}$ & $1755 \mathrm{c}$ \\
\hline & 10 & $828 \mathrm{a}$ & $916 \mathrm{a}$ & $978 \mathrm{a}$ & $1037 \mathrm{a}$ & $1079 \mathrm{a}$ & $1092 \mathrm{a}$ & $1148 \mathrm{a}$ & $1162 \mathrm{a}$ \\
\hline & & \multicolumn{8}{|c|}{$\mathrm{CV}(\%)=4.5$} \\
\hline & & \multicolumn{8}{|c|}{50 seeds $/ 75 \mathrm{~mL} / 30^{\circ} \mathrm{C}$} \\
\hline \multirow{6}{*}{ AP8203 } & 1 & $451 \mathrm{a}$ & $642 \mathrm{a}$ & $734 \mathrm{a}$ & $814 \mathrm{a}$ & 841 a & $912 \mathrm{a}$ & $984 \mathrm{a}$ & $1116 \mathrm{a}$ \\
\hline & 2 & $839 \mathrm{~b}$ & $921 \mathrm{~b}$ & $1046 \mathrm{~b}$ & $1122 b$ & $1153 \mathrm{~b}$ & $1274 \mathrm{~b}$ & $1309 \mathrm{~b}$ & $1411 b$ \\
\hline & 3 & $425 \mathrm{a}$ & $578 \mathrm{a}$ & $671 \mathrm{a}$ & $750 \mathrm{a}$ & $775 \mathrm{a}$ & $845 \mathrm{a}$ & $915 \mathrm{a}$ & $1005 \mathrm{a}$ \\
\hline & 4 & $888 \mathrm{~b}$ & $1036 \mathrm{~b}$ & $1110 \mathrm{~b}$ & $1155 \mathrm{~b}$ & $1183 \mathrm{~b}$ & $1257 \mathrm{~b}$ & $1292 \mathrm{~b}$ & $1409 \mathrm{~b}$ \\
\hline & 5 & $456 \mathrm{a}$ & $638 \mathrm{a}$ & $704 \mathrm{a}$ & $764 \mathrm{a}$ & $848 \mathrm{a}$ & 889 a & $980 \mathrm{a}$ & $1044 \mathrm{a}$ \\
\hline & & \multicolumn{8}{|c|}{$\mathrm{CV}(\%)=4.2$} \\
\hline \multirow{6}{*}{ AP4512 } & 6 & $782 \mathrm{a}$ & 885 a & 887 a & 927 a & 929 a & $941 \mathrm{a}$ & $1061 \mathrm{a}$ & $1111 \mathrm{a}$ \\
\hline & 7 & $1276 \mathrm{~b}$ & $1287 \mathrm{~b}$ & $1319 b$ & $1332 \mathrm{~b}$ & $1342 \mathrm{~b}$ & $1345 \mathrm{~b}$ & $1354 \mathrm{~b}$ & $1395 \mathrm{~b}$ \\
\hline & 8 & $1453 \mathrm{c}$ & $1548 \mathrm{c}$ & $1553 \mathrm{c}$ & $1559 \mathrm{c}$ & $1585 \mathrm{c}$ & $1596 \mathrm{c}$ & $1667 \mathrm{c}$ & $1682 \mathrm{c}$ \\
\hline & 9 & $1220 \mathrm{~b}$ & $1226 \mathrm{~b}$ & $1269 b$ & $1285 \mathrm{~b}$ & $1310 \mathrm{~b}$ & $1374 \mathrm{~b}$ & $1384 \mathrm{~b}$ & $1393 \mathrm{~b}$ \\
\hline & 10 & $766 \mathrm{a}$ & $853 \mathrm{a}$ & $921 \mathrm{a}$ & $983 \mathrm{a}$ & $1022 \mathrm{a}$ & $1037 \mathrm{a}$ & $1090 \mathrm{a}$ & $1105 \mathrm{a}$ \\
\hline & & \multicolumn{8}{|c|}{$\mathrm{CV}(\%)=4.5$} \\
\hline
\end{tabular}

Mean values followed by the same letter in the column do not statistically differ from each other by the Tukey test at $5 \%$ probability.

Table 5. Mean data obtained for potassium leaching ( $\mu \mathrm{g} \mathrm{K} / \mathrm{g}$ ) using the combinations of $100 \mathrm{seeds} / 50 \mathrm{~mL}$ of water and 100 seeds $/ 75 \mathrm{~mL}$ of water at $30^{\circ} \mathrm{C}$ of five lots of hybrid popcorn seeds, AP8203 and AP4512.

\begin{tabular}{|c|c|c|c|c|c|c|c|c|c|}
\hline \multirow{3}{*}{ Hybrid } & \multirow{3}{*}{ Lot } & \multicolumn{8}{|c|}{ Soaking period } \\
\hline & & 0.5 & 1 & 1.5 & 2 & 2.5 & 3 & 4 & 5 \\
\hline & & \multicolumn{8}{|c|}{100 seeds $/ 50 \mathrm{~mL} / 30^{\circ} \mathrm{C}$} \\
\hline \multirow{5}{*}{ AP8203 } & 1 & $551 \mathrm{a}$ & $674 \mathrm{a}$ & $740 \mathrm{a}$ & $817 \mathrm{a}$ & $872 \mathrm{a}$ & $914 \mathrm{a}$ & 997 a & $1075 \mathrm{a}$ \\
\hline & 2 & $546 \mathrm{a}$ & $685 \mathrm{a}$ & 777 a & $864 \mathrm{a}$ & $931 \mathrm{a}$ & $1145 \mathrm{~b}$ & $11192 \mathrm{~b}$ & $1250 \mathrm{~b}$ \\
\hline & 3 & $973 \mathrm{c}$ & $1103 \mathrm{c}$ & $1176 \mathrm{c}$ & $1220 \mathrm{c}$ & $1270 \mathrm{c}$ & $1319 \mathrm{c}$ & $1398 \mathrm{c}$ & $1441 \mathrm{c}$ \\
\hline & 4 & $827 \mathrm{bc}$ & 944 bc & $1012 b c$ & $1105 \mathrm{bc}$ & $1165 \mathrm{bc}$ & $1195 \mathrm{bc}$ & $1272 \mathrm{bc}$ & $1312 \mathrm{bc}$ \\
\hline & 5 & 596 a & $678 \mathrm{a}$ & $744 \mathrm{a}$ & $796 \mathrm{a}$ & 849 a & $888 \mathrm{a}$ & $964 \mathrm{a}$ & $1053 \mathrm{a}$ \\
\hline
\end{tabular}

Continue... 
Table 5. Continuation.

\begin{tabular}{|c|c|c|c|c|c|c|c|c|c|}
\hline \multirow{3}{*}{ Hybrid } & \multirow{3}{*}{ Lot } & \multicolumn{8}{|c|}{ Soaking period } \\
\hline & & 0.5 & 1 & 1.5 & 2 & 2.5 & 3 & 4 & 5 \\
\hline & & \multicolumn{8}{|c|}{100 seeds $/ 50 \mathrm{~mL} / 30^{\circ} \mathrm{C}$} \\
\hline \multirow{7}{*}{ AP4512 } & 6 & $812 \mathrm{a}$ & $875 \mathrm{a}$ & $1036 \mathrm{a}$ & $1037 \mathrm{a}$ & $1079 \mathrm{a}$ & $1095 \mathrm{a}$ & $1156 \mathrm{a}$ & 1159 a \\
\hline & 7 & $1263 \mathrm{~b}$ & $1385 \mathrm{~b}$ & $1421 \mathrm{~b}$ & $1425 b$ & $1435 \mathrm{~b}$ & $1439 \mathrm{~b}$ & $1447 \mathrm{~b}$ & $1449 \mathrm{~b}$ \\
\hline & 8 & $794 \mathrm{a}$ & 919 a & $967 \mathrm{a}$ & $976 \mathrm{a}$ & $979 \mathrm{a}$ & $995 \mathrm{a}$ & $996 \mathrm{a}$ & 997 a \\
\hline & 9 & $1407 \mathrm{c}$ & $1518 \mathrm{c}$ & $1565 \mathrm{~b}$ & $1568 \mathrm{~b}$ & $1572 \mathrm{~b}$ & $1576 \mathrm{~b}$ & $1579 \mathrm{~b}$ & $1585 \mathrm{~b}$ \\
\hline & 10 & $745 \mathrm{a}$ & $864 \mathrm{a}$ & $932 \mathrm{a}$ & $945 \mathrm{a}$ & $975 \mathrm{a}$ & $994 \mathrm{a}$ & $1031 \mathrm{a}$ & 1037 \\
\hline & & \multicolumn{8}{|c|}{$\mathrm{CV}(\%)=4.7$} \\
\hline & & \multicolumn{8}{|c|}{100 seeds $/ 75 \mathrm{~mL} / 30^{\circ} \mathrm{C}$} \\
\hline \multirow{6}{*}{ AP8203 } & 1 & $525 \mathrm{a}$ & $633 \mathrm{a}$ & 709 a & $772 \mathrm{a}$ & 833 a & $878 \mathrm{a}$ & $952 \mathrm{a}$ & $1036 \mathrm{a}$ \\
\hline & 2 & $507 \mathrm{a}$ & $642 \mathrm{a}$ & $736 \mathrm{a}$ & $821 \mathrm{a}$ & $892 \mathrm{a}$ & $1109 \mathrm{~b}$ & $1151 \mathrm{~b}$ & $1215 \mathrm{~b}$ \\
\hline & 3 & $935 \mathrm{c}$ & $1061 \mathrm{~b}$ & $1137 \mathrm{~b}$ & $1188 \mathrm{~b}$ & $1248 \mathrm{~b}$ & $1275 \mathrm{c}$ & $1355 \mathrm{c}$ & $1414 \mathrm{c}$ \\
\hline & 4 & $789 \mathrm{~b}$ & $908 \mathrm{~b}$ & $977 \mathrm{~b}$ & $1063 \mathrm{~b}$ & $1129 \mathrm{~b}$ & $1152 \mathrm{bc}$ & $1234 \mathrm{bc}$ & $1278 \mathrm{bc}$ \\
\hline & 5 & $562 \mathrm{a}$ & $637 \mathrm{a}$ & $701 \mathrm{a}$ & $751 \mathrm{a}$ & $810 \mathrm{a}$ & $841 \mathrm{a}$ & $927 \mathrm{a}$ & $1019 \mathrm{a}$ \\
\hline & & \multicolumn{8}{|c|}{$\mathrm{CV}(\%)=4.5$} \\
\hline \multirow{6}{*}{ AP4512 } & 6 & $774 \mathrm{a}$ & 871 a & $990 \mathrm{a}$ & $995 \mathrm{a}$ & $1035 \mathrm{a}$ & $1054 \mathrm{a}$ & $1112 \mathrm{a}$ & $1114 \mathrm{a}$ \\
\hline & 7 & $1228 \mathrm{~b}$ & $1345 \mathrm{~b}$ & $1381 \mathrm{~b}$ & $1384 \mathrm{~b}$ & $1397 \mathrm{~b}$ & $1403 \mathrm{~b}$ & $1406 \mathrm{~b}$ & $1409 \mathrm{~b}$ \\
\hline & 8 & $760 \mathrm{a}$ & 878 a & $925 \mathrm{a}$ & $933 \mathrm{a}$ & 938 a & $950 \mathrm{a}$ & $955 \mathrm{a}$ & $965 \mathrm{a}$ \\
\hline & 9 & $1372 \mathrm{c}$ & $1474 \mathrm{c}$ & $1537 \mathrm{c}$ & $1538 \mathrm{c}$ & $1541 \mathrm{c}$ & $1545 \mathrm{c}$ & $1549 \mathrm{c}$ & $1551 \mathrm{c}$ \\
\hline & 10 & $704 \mathrm{a}$ & $826 \mathrm{a}$ & 896 a & $906 \mathrm{a}$ & $939 \mathrm{a}$ & $958 \mathrm{a}$ & $1013 \mathrm{a}$ & $1034 \mathrm{a}$ \\
\hline & & \multicolumn{8}{|c|}{$\mathrm{CV}(\%)=3.9$} \\
\hline
\end{tabular}

Mean values followed by the same letter in the column do not statistically differ from each other by the Tukey test at $5 \%$ probability.

$(\mathrm{p}<0.05)$ correlated with seedling emergence, corroborating the results obtained by Araújo and Silva (2018) and Steiner et al. (2011) in evaluation of seed lots of Encholirium spectabile and triticale, respectively. The results of significant $(p<0.05)$ and negative correlation between the potassium leaching test and emergence of seedlings in a greenhouse are similar to those found by Douradinho et al. (2015) and Barbieri et al. (2011) in wheat and rice seeds, respectively. Thus, as the exudates from potassium leaching increase, the emergence of popcorn seedlings in the field declines.

In general, for both hybrids, there was significant potassium leaching in the first thirty minutes of soaking of popcorn seeds. However, leaching occurred at lower intensity up to five hours of soaking. This was also confirmed by Zucareli et al. (2013) in sweet corn seeds. Barbieri et al. (2011) also found higher potassium leaching readings at 120 minutes of soaking of rice seeds. In short, when seed membranes are directly soaked, they pass from the gel state to the liquid crystalline state (Castro et al., 2004). However, when this transition occurs rapidly, there is not enough time for the membranes to change their structural conformation, and this situation brings about cell damage and electrolyte leaching (Silva and Villela, 2011).
Table 6. Correlation coefficient ( $\mathrm{r}$ ) between seed physiological quality evaluation and field emergence tests in two hybrids and five lots of popcorn AP8203 and AP4511.

\begin{tabular}{ccccc}
\hline Hybrid & Test & First count & $\begin{array}{c}\text { Potassium } \\
\text { leaching }\end{array}$ & Emergence \\
\hline \multirow{2}{*}{ AP8203 } & Gemination & $0.983^{*}$ & $-0.897^{*}$ & $0.955^{*}$ \\
& $\begin{array}{c}\text { First count } \\
\text { Potassium } \\
\text { leaching }\end{array}$ & - & $-0.903^{*}$ & $0.942^{*}$ \\
\hline \multirow{2}{*}{ AP4511 } & $\begin{array}{c}\text { Gemination } \\
\text { First count }\end{array}$ & $0.927^{*}$ & $-0.915^{*}$ & $0.932^{*}$ \\
& $\begin{array}{c}\text { Potassium } \\
\text { leaching }\end{array}$ & - & $-0.899^{*}$ & $0.916^{*}$ \\
\hline
\end{tabular}

*r significant at $5 \%$ probability.

\section{Conclusions}

The potassium leaching test is efficient in discriminating popcorn seed lots in relation to physiological potential. The most suitable conditions for carrying out this test are use of 50 seeds with $50 \mathrm{~mL}$ of water for 2 hours at $30^{\circ} \mathrm{C}$. 


\section{References}

ARAÚJO, A.V.; SILVA, M.A.D. Avaliação do potencial fisiológico de sementes de Encholirium spectabile Mart. ex Schult. e Schult. f. Ciência Florestal, v.28, n.1, p.56-66, 2018. http://www.scielo. br/scielo.php?pid=S1980-50982018000100056\&script $=$ sci abstract\&tlng $=\mathrm{pt}$

ARAUJO, R.F.; ZONTA, J.B.; ARAUJO, E.F.; HEBERLE, E.; ZONTA, F.M.G. Teste de condutividade elétrica para sementes de feijão-mungo-verde. Revista Brasileira de Sementes, v.33, n.1, p.123-130, 2011. http://www.scielo.br/scielo.php?pid=S0101$31222011000100014 \&$ script $=$ sci_abstract\&tlng $=$ es

AVELINO, M.C.S.; FELIX, F.C.; SILVA, K.R.G.; ARAÚJO, F.S.; PACHECO, M.V. Testes bioquímicos de integridade de membranas na avaliação do vigor de sementes de Mimosa caesalpiniifolia Benth. Revista de Ciências Agrárias, v.41, n.1, p.100-108, 2018. http://www.scielo.mec.pt/pdf/rca/v41n1/v41n1a11.pdf

BARBIERI, A.P.P.; MENEZES, N.L.; CONCEIÇÃO, G.M.; TUNES, L.M. Teste de lixiviação de potássio para a avaliação do vigor de sementes de arroz. Revista Brasileira de Sementes, v.33, n.4, p.616-625, 2011. http://www.scielo.br/scielo.php?pid=S0101$31222012000100015 \&$ script $=$ sci_abstract\&tlng $=$ pt

BERTOLIN, D.C.; SÁ, M.E.; MOREIRA, E.R. Parâmetros do teste de envelhecimento acelerado para determinação do vigor de sementes de feijão. Revista Brasileira de Sementes, v.33, n.1, p.104-112, 2011. http://www.scielo.br/scielo.php?pid=S0101$31222011000100012 \&$ script $=$ sci_abstract\&tlng $=$ pt

BITTENCOURT, S.R.M.; GRZYBOWSKI, C.R.S.; PANOBIANCO, M.; VIEIRA, R.D. Metodologia alternativa para condução do teste de envelhecimento acelerado em sementes de milho. Ciência Rural, v.42, n.8, p.1360-1365, 2012. http:/www.scielo.br/scielo.php?script=sci_ abstract\&pid $=$ S0103-84782012000800005\&lng=pt\&nr m=iso

BRASIL. Ministério da Agricultura, Pecuária e Abastecimento. Regras para análise de sementes. Ministério da Agricultura, Pecuária e Abastecimento. Secretaria de Defesa Agropecuária. Brasília: MAPA/ACS, 2009. 395p. http:// www.agricultura.gov.br/ arq_editor/file/2946_regras_analise_sementes.pdf

CASTRO, R.D.; BRADFORD, K.J.; HILHORST, H.W.M. Embebição e reativação do metabolismo. In: FERREIRA, A.G.; BORGHETTI, F. (ed.). Germinação - do básico ao aplicado. Porto Alegre: Artmed, 2004. p.149-162.

CATÃO, H.C.R.M.; CAIXETA, F. Physiological, isozyme changes and image analysis of popcorn seeds submitted to low temperatures. Journal of Seed Science, v.39, n.3, p.234-243, 2017. http://www.scielo.br/scielo. php?pid=S2317-15372017000300234\&script=sci_abstract\&tlng=en

CATÃO, H.C.R.M.; CAIXETA, F. Electrical conductivity test in soybean seeds with reduced imbibition period. Revista de Ciências Agrárias, v.42, n.2, p.40-48, 2019. http://www.scielo.mec.pt/scielo. php?script=sci_arttext\&pid=S0871-018X2019000200010\&lng=en \&nrm=iso\&tlng $=$ en
CATÃO, H.C.R.M.; MAGALHÃES, H.M.; SALES, N.L.P.; BRANDÃO-JUNIOR, D.S.; ROCHA, F.S. Incidência e viabilidade de sementes crioulas de milho naturalmente infestadas com fungos em pré e pós-armazenamento. Ciência Rural, v.43, n.5, p.764-770, 2013. http://www.scielo.br/scielo.php?script=sci_arttext\&pid=S0103$84782013000500002 \& \operatorname{lng}=\mathrm{en} \& \mathrm{nrm}=\mathrm{iso} \& \operatorname{tlng}=\mathrm{pt}$

DOURADINHO, G.Z.; SOUZA， G.E.; OLIVEIRA， C.P.; BORTOLAZZO, G.; ZOZ, T.; STEINER, F. Teste de lixiviação de potássio para avaliação rápida do vigor de sementes de trigo. Revista de Agricultura Neotropical, v.2, n.3, p.18-22, 2015. https:// periodicosonline.uems.br/index.php/agrineo/article/view/266

FERREIRA, D.F. Sisvar: a computer statistical analysis system. Ciência e Agrotecnologia, v.35, n.6, p.1039-1042, 2011. http://www.scielo.br/ scielo.php?script=sci arttext\&pid=S1413-70542011000600001

GONZÁLES, J.L.S.; VALERI, S.V.; PAULA, R.C. Qualidade fisiológica de sementes de diferentes árvores matrizes de Corymbia citriodora (Hook.) K.D. Hill and L.A.S. Johnson. Scientia Florestalis, v.39, n.90, p.171-181, 2011. https://www.ipef.br/ publicacoes/scientia/nr90/cap05.pdf

GUEDES, R.S.; ALVES, E.U.; OLIVEIRA, L.S.B.; ANDRADE, L.A.; GONÇALVES, E.P.; MELO, P.A.R.F. Envelhecimento acelerado na avaliação da qualidade fisiológica de sementes de Dalbergia nigra (Vell.) Fr. All. Semina: Ciências Agrárias, v.32, n.2, p.443-450, 2011. http://www.uel.br/revistas/uel/index.php/ semagrarias/article/viewFile/3247/8404

KAVAN, H.C.; CATÃO, H.C.R.M.; CAIXETA, F.; ROCHA, C.S.; CASTILHO, I.M. Accelerated aging periods and its effects on electric conductivity of popcorn seeds. Revista de Ciências Agrárias, v.42, n.1, p.40-48, 2019. http://www.scielo.mec.pt/scielo.php?script=sci abstract\&pid=S0871-018X2019000100006\&lng-pt \&nr m=iso\&tlng=e-

MARCOS-FILHO, J.; NOVEMBRE, A.D.L.C. Avaliação do potencial fisiológico de sementes de hortaliças. In: NASCIMENTO, W.M. (ed.). Tecnologia de sementes de hortaliças. Brasília, DF: EMBRAPA Hortaliças, 2019. p.185-246.

MARCOS-FILHO, J. Fisiologia de sementes de plantas cultivadas. Piracicaba: FEALQ, 2005. 495p.

NAKAGAWA, J. Testes de vigor baseados na avaliação das plântulas. In: VIEIRA, R.D.; CARVALHO, N.M. Testes de vigor em sementes. Jaboticabal: FUNEP, 1999. p.49-85.

ROCHA, C.S.; CATÃO, H.C.R.M.; CAIXETA, F.; KAVAN, H.K.; CLAUDINO, T.M.; CAIXETA, D.G. Physiological quality of popcorn seeds assessed by the accelerated aging test. Journal of Seed Science, v.40, n.4, p.428-434, 2018. http://www.scielo.br/scielo. php?script=sci_arttext\&pid=S2317-15372018000400428

SILVA, K.R.G.; VILLELA, F.A. Pré-hidratação e avaliação do potencial fisiológico de sementes de soja. Revista Brasileira de Sementes, v.33, n.2, p.331-345, 2011. http://www.scielo.br/scielo. php?pid=S0101-31222011000200016\&script $=$ sci_abstract\&tlng $=$ pt

SOUZA, G.E.; STEINER, F.; ZOZ, T.; OLIVEIRA, S.S.C.; CRUZ, S.J.S. Comparação entre métodos para a avaliação do vigor de sementes de algodão. Revista de Agricultura Neotropical, v.1, n.2, p.35-41, 2014. https://periodicosonline.uems.br/index.php/agrineo/article/view/237 
STEINER, F.; OLIVEIRA, S.S.C.; MARTINS, C.C.; CRUZ, S.J.S. Comparação entremétodos paraa avaliação dovigorde lotes desementes de triticale. Ciência Rural, v.41, n.2, p.200-204, 2011. http://www. scielo.br/scielo.php?pid=S0103-84782011000200002\&script $=$ sci_ abstract\&tlng=pt
ZUCARELI, C.; BRZEZINSKI, C.R.; ABATI, J.; HENNING, F.A.; RAMOS-JUNIOR, E.U.; NAKAGAWA, J. Lixiviação de íons potássio, cálcio e magnésio para a determinação do vigor em sementes de milho doce. Informativo ABRATES, v.23, n.3, p.5660, 2013. https://www.embrapa.br/soja/busca-de-publicacoes/-/ publicacao/981118/lixiviacao-de-ions-potassio-calcio-e-magnesiopara-determinacao-do-vigor-em-sementes-de-milho-doce

This is an Open Access article distributed under the terms of the Creative Commons Attribution License, which permits unrestricted use, distribution, and reproduction in any medium, provided the original work is properly cited. 